\title{
60 años del Cineclub Vida: un espacio de cultura y libertad en Sevilla
}

\begin{abstract}
En 1957, en Sevilla, la Compañía de Jesús crea el Cineclub Vida con el propósito de fomentar la dimensión crítica de la persona a partir del cine, organizando la presentación, proyección y posterior comentario de películas consideradas de interés. Este año 2017 la institución cultural cumple sesenta años de actividad ininterrumpida, seis décadas en las que se ha convertido en el tercer cineclub más longevo de España y el más prestigioso a nivel andaluz.
\end{abstract}

Aurora Villalobos Gómez | Cineclub Vida

URL de la contribución <www.iaph.es/revistaph/index.php/revistaph/article/view/3928>

El primer cineclub fue creado en 1920, en París, por el teórico y director Louis Delluc, vinculado a Le Journal du Ciné-club. Sirve como lugar de encuentro de creadores y críticos que conciben el cine como el arte de vanguardia representativo del nuevo siglo, con sus propios recursos expresivos. Esta fórmula experimental y minoritaria llega a España en 1928, cuando el director Luis Buñuel organiza en la Residencia de Estudiantes una serie de proyecciones cinematográficas integradas con charlas, conciertos y lecturas; precedente del Cineclub Español, vinculado a La Gaceta Literaria. Son muchos los cineclubes que proliferan en los sucesivos años hasta la Guerra Civil, pero no es hasta 1955 cuando este fenómeno recibe un impulso inesperado con la alocución de Pío XII a productores y directores de cine italiano, proponiéndoles comprender el "film ideal" como un medio de comunicación y formación en valores. En este contexto es creado en 1957, en Sevilla, el Cineclub Vida por la Compañía de Jesús con el propósito de fomentar la dimensión crítica de la persona a partir del cine.

Se trata de una experiencia que ha enriquecido el imaginario cultural de diversas generaciones al proyectar en versión original casi mil películas ajenas a los circuitos comerciales; al tiempo que ha desarrollado la capacidad crítica de los asistentes con un posterior coloquio moderado por diversos especialistas donde la clave ha sido siempre la participación. Esto lo ha convertido en un auténtico espacio para la cultura y la libertad desde sus primeras etapas, pudiendo decir que al día de hoy es un referente intercultural, interdisciplinar e intergeneracional.

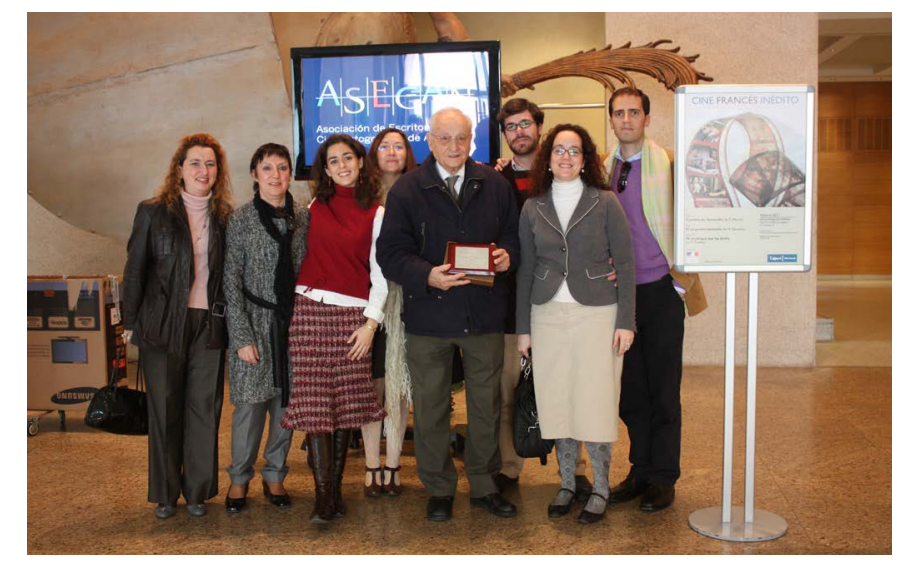

Premio de Honor ASECAN al Cineclub Vida y a su director Manuel Alcalá LópezBarajas | foto Aurora Villalobos Gómez, 5 febrero 2011

Intercultural porque a través de la programación de sus ciclos ha dado a conocer una visión compleja del mundo con cinematografías de distintas procedencias y temáticas comprometidas con la actualidad. Esto ha supuesto la colaboración con otras instituciones culturales para acceder en versión original a un selecto repertorio clásico y de vanguardia; asimismo, ha atraído la presencia renovada de público extranjero que en el coloquio ha intercambiado experiencias y aportado comentarios esclarecedores de su cultura. Con esta premisa, el Cineclub Vida se adelanta a la Ley 16/1985, de 25 de junio, del Patrimonio Histórico Español cuando enuncia en su preámbulo que "en un Estado democrático estos bienes deben estar adecuadamente puestos al servicio de la colectividad en el convencimiento de que con su disfrute se facilita el acceso a la cultura y que ésta, en definitiva, es camino seguro hacia la libertad de los pueblos". 


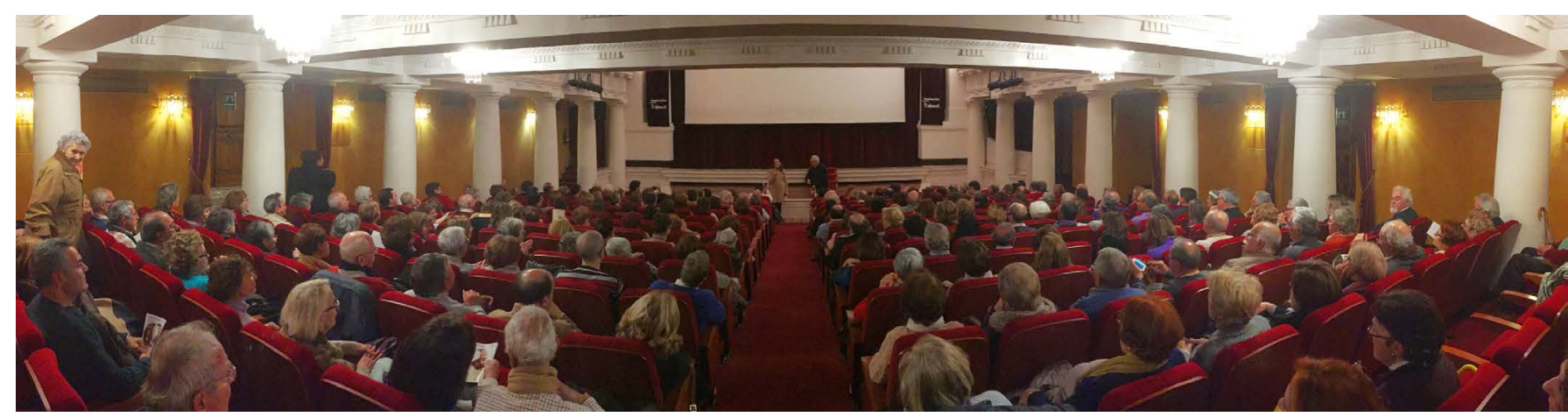

Ciclo de Cine y Patrimonio Cultural en la Sala Chicarreros de la Fundación Cajasol en Sevilla | foto José Manuel Hinojosa-de-Guzmán Alonso, 3 de enero de 2015

Interdisciplinar porque en el planteamiento del coloquio ha integrado la visión complementaria del cine como arte, técnica y medio de comunicación en el concepto más amplio de patrimonio cultural; que requiere de una estrategia de conocimiento plural para la valorización del cine como objeto patrimonializable. Esto ha permitido enriquecer los enfoques incorporando a la crítica cinematográfica cuestiones de historia, filosofía, fotografía, literatura, música, arquitectura... De manera recíproca, ha habido ocasión para reflexionar sobre el cine como recurso patrimonializador que construye nuestra manera de entender el mundo a través de la mostración, transformación e invención de la realidad. Estas relaciones poliédricas entre cine y patrimonio ponen de manifiesto la necesidad de más estudios especializados sobre los criterios de reconocimiento de nuevos registros audiovisuales como Memoria del Mundo, la conservación de posibles bienes materiales asociados, visiones y ficciones del patrimonio en el cine, historia e historiografía del cine, el cine como fuente histórica, metodología de análisis del género histórico, pedagogía del cine...

Intergeneracional porque, como foco cultural en la ciudad, ha consolidado en cada etapa un equipo estable de colaboradores y fidelizado un público heterogéneo. En este sentido cabe destacar sus primeros veinte años como lugar de encuentro de jóvenes universitarios deseosos de cambiar el mundo, con el paso del tiempo convertidos en personalidades de la cultura y la política a nivel nacional. Esta continuidad, a pesar de los cambios de contexto político y socio cultural, sólo puede entenderse por tres factores: el fuerte vínculo establecido con la ciudad al adelantarse a las necesidades culturales de los tiempos; la consolidación de un formato reconocido que tiene por señas de identidad: la calidad, diversidad y libertad de expresión; y la impronta de su director más veterano, Manuel Alcalá López-Barajas (Granada, 1926), que representa el vínculo de la actualidad con sus orígenes.

Esta creación de sinergias excede el propio ámbito del Cineclub Vida, pudiendo plantearse su comprensión como un patrimonio vivo de la ciudad, lo que UNESCO define como un patrimonio inmaterial que "no es solamente sede de la memoria de la cultura de ayer, sino también el laboratorio donde se inventa el mañana".

\section{BIBLIOGRAFÍA}

- AA. VV. (2005) Especial Monográfico: Patrimonio cinematográfico. Revista PH, n. ${ }^{\circ}$ 56, $2005<$ http://www.iaph.es/ revistaph/index.php/revistaph/issue/view/56> [Consulta: 21/04/2017]

- CAMPORESI, V. (2014) Pensar la historia del cine. Madrid: Cátedra, 2014

- díEZ PUERTAS, E. (2003) Historia social del cine en España. Madrid: Editorial Fundamentos, 2003

- UTRERA MACíAS, R. (2008) El cine-club Vida de Sevilla. 50 años de historia. Sevilla: Fundación Cajasol, 2008

- VILLALOBos GómeZ, A. (2015) La función social del cine como recurso patrimonializador. En Actas del IX Congreso Internacional AR\&PA. Sociedad y Patrimonio. Valladolid: Diputación Provincial de Valladolid. Junta de Castilla y León, 2015, pp. 91-104 <https://t.co/Ow19elfz8f> [Consulta: 21/04/2017] 